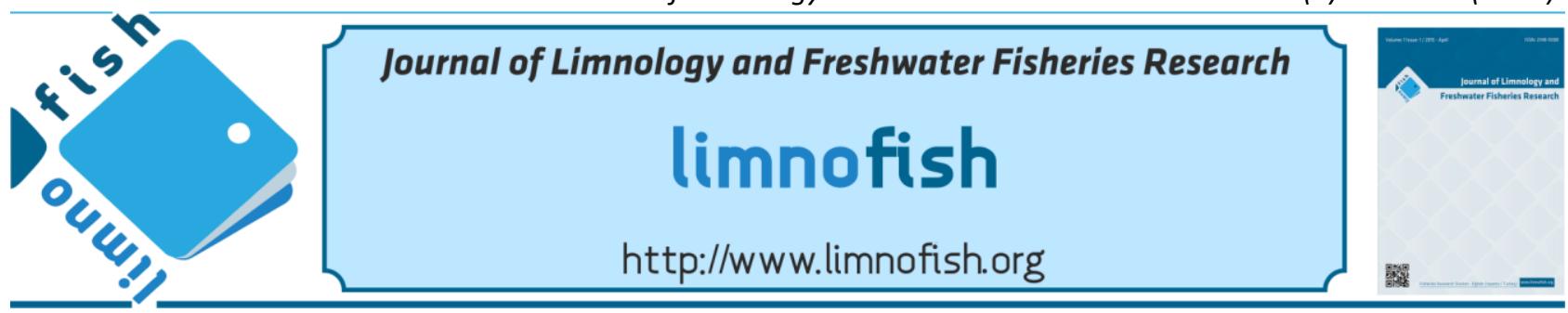

\title{
Morphological Diversification of Mesocyclops leuckarti (Claus, 1857)
}

\author{
Mehmet Fatih CAN* iD, Ahmet BOZKURT iD \\ Faculty of Marine Science and Technology, İskenderun Technical University, Hatay, Turkey
}

\section{A B S TRACT}

In this study, different populations of a copepod species, Mesocyclops leuckarti, were compared with their body size. Samples were taken from Asi River, Mehmetli Dam Lake, Yenişehir Lake, and Tahta Köprü Dam Lake, locating in east-south part of Turkey. Whole sexual dimorphism for the populations was changed from 1.56 to 1.62 . Intra-population variability on body size by locations were changed as $3.85 \%$ to $5.05 \%$. Intra-population variability was bigger in male than that of female populations in each water body. The same pattern was observed for inter-population variability among male populations $(8.46 \%)$ and female populations $(8.04 \%)$. Discriminant analysis $(D F A)$ and SIMPER (Similarity Percentage) methods revealed that Cephalozom Length $(C L)$ measurementwas the most distinguished measure leading discriminate among the male populations with $23.97 \%$. Abdomen $(A B D)$ measurement was the most discriminative measure among female populations with $30.86 \%$. Based on the $M A N O V A$, the differentiation in body size among the female populations was very significant $(\mathrm{p}<0.001)$, contrary to male populations $(\mathrm{p}>0.05)$. The Minimal Spanning Tree (MST) analysis showed that the specimen living in the pond and lake systems were closer than river systems in terms of body size diversification especially for female ones of copepods.

Keywords: Copepoda, Mesocyclops leuckarti, body size, variability, sexual dimorphism

\section{ARTICLE INFO}

\section{RESEARCH ARTICLE}

Received : 05.02.2019

Revised : :05.05.2019

Accepted : : 14.05.2019

Published : :25.12.2019

DOI:10.17216/LimnoFish.522694

\section{* CORRESPONDING AUTHOR}

mfatih.can@iste.edu.tr

Phone : (+90) 3266141693

\section{Mesocyclops leuckarti (Claus, 1857) nin Morfolojik Çeşitliliği \\ Öz: Bu çalışmada, bir kopepod türü olan Mesocyclops leuckarti nin vücut büyüklüğü farklı popülasyonları arasında karşılaştırıldı. Örnekler Türkiye nin Güney Doğusunda yer alan Asi Nehri, Mehmetli Baraj Gölü, Yenişehir Gölü ve Tahta Köprü Baraj Gölü'nden alındı. Popülasyonları için genel eşeysel dimorfizim 1,56 ile 1,62 arasında değişti. Lokasyonlara göre, popülasyonlar içi vücut büyüklügünndeki değişim \% 3,85 ile \% 5,05 arasında değişmiştir. Her bir su kütlesinde erkeklerin popülasyonlar içi değişimleri dişilere göre daha fazla idi. Aynı model erkek popülasyonları $(\%$ 8,46) arasında ve dişi popülasyonları $(\%$ 8,04) arasında da gözlemlenmiştir. Diskriminant analizi ( $D F A)$ ve SIMPER (Benzerlik Yüzdesi) yöntemleri, Cephalozom Uzunluk $(C L)$ ölçümünün, erkek popülasyonları arasında \% 23,97 ile ayrışmaya yol açan en belirgin ölçüm olduğunu ortaya koydu. Abdomen $(A B D)$ ölçümü dişi popülasyonlar içinde \% 30,86 ile en fazla ayrışmaya yol açan ölçüm idi. MANOVA' ya göre, dişi popülasyonları arasında vücut büyüklüğündeki farklılaşma, erkek popülasyonların aksine $(\mathrm{p}>0,05)$ çok anlamlıydı $(\mathrm{p}<0,001)$. Minimal Yayılma Ağacı $(M S T)$ analizi, vücut büyüklüğü farklılaşması açısından özellikle kopepod' ların dişileri için, gölet ve göl sistemlerinde yaşayan bireylerin nehir sistemlerinde yaşayan bireylere göre birbirlerine daha yakın olduğunu göstermiştir.}

Anahtar kelimeler: Copepoda, Mesocyclops leuckarti, vücut büyüklüğü, değişkenlik, eşeysel dimorfizim

\section{How to Cite}

Can MF, Bozkurt A. 2019. Morphological Diversification of Mesocyclops leuckarti (Claus, 1857) LimnoFish. 5(3): 204-212. doi: 10.17216/LimnoFish.522694

\section{Introduction}

Animal species distributed over wide geographic areas are usually split into subspecies. According to current theory, geographic variation and isolation are important factors in the process of speciation (Elgmork and Halvorsen 1998). Therefore, expecting the influence of geographic isolation on any dynamics of species, including on body size, may reasonable. There is growing recognition that both inter-specific and intra-specific variations can have significant effects on population, community, and ecosystem dynamics. Morphological differences are likely a key component of this ecologically important variation (Hausch et al. 2013). As a fundamental 
morphological parameter, body size largely determines species' functional and environmental characteristics, growth, life duration, population density, and species' place in food webs (Anufriieva and Shadrin 2014).

The Cyclopoida is the most species-rich group among copepod lineages and comprises, the largest group within the subclass Copepoda. Members of the copepods are important components of pelagic ecosystems. Several cyclopoid copepod species among the genus Mesocyclops have invaded different places of the world, each showing distinct distributional patterns (Reid and Saunders 1986; Reid and Pinto-Coelho 1994; Hribar and Reid 2008; Suárez-Morales et al. 2011).

Morphometric variability of some copepod species was studied in different water bodies in the world (Hausch et al. 2013; Anufriieva and Shadrin 2014; Anufriieva and Shadrin 2015) and the size of copepods is affected by a number of environmental factors and varies widely (Anufriieva and Shadrin 2015). However, little effort has been made, for copepods or any other taxonomic groups, to quantify morphological variation among populations relative to that among species. It was expressed as unexpected that both inter-specific and intra-specific diversity has important effects on species coexistence and ecosystem dynamics. While intra-specific diversity is maintained both within and between populations, comparisons of inter to intra-specific diversity appear to have focused exclusively on comparing diversity between species to that within local populations (Hausch et al. 2013).

The aim of our study, is to determine both interpopulation and intra-population diversity on body size, as an indicator of morphological differentiation, of $M$. leucarti from the different water bodies, locating in the Southeast Region of Turkey. We analyzed both variability by partition the morphological variation into components by sexes and populations.

\section{Materials and Methods \\ Sampling}

Zooplankton samples were taken from four different localities in Turkey. M. leuckarti were collected from Tahta Köprü Dam Lake (36 ${ }^{\circ} 52$ 22.19" K, 36 $41^{\circ} 20.31^{\prime \prime} \mathrm{D}$, for 12 months), Mehmetli Dam Lake $\left(37^{\circ} 30^{\prime} 31.79^{\prime \prime} \mathrm{K}, 36^{\circ} 01^{\prime} 09.37^{\prime \prime} \mathrm{D}\right.$, on the 7 th of October 2009, 16th of July 2010, and 13th of April 2010), Yenişehir Lake ( $36^{\circ} 14^{\prime} 12.17^{\prime \prime} \mathrm{K}, 36^{\circ} 34^{\prime} 08.38^{\prime \prime}$ $\mathrm{D}$, for 12 months in 2003 and 2004) and Asi River $\left(36^{\circ} 13^{\prime} 00.54^{\prime \prime} \mathrm{K}, 36^{\circ} 09^{\prime} 44.42^{\prime \prime} \mathrm{D}\right.$, for 12 months in 2005 and 2006) with horizontal and vertical draws by using $60 \mu \mathrm{m}$ mesh size plankton net. Samples were replaced into a glass jar and fixed with $4 \%$ formaldehyde. Then, the selected adult $M$. leuckarti specimens were put in ethanol due to health concerns of formaldehyde. The copepod specimen examination, counting, and measurements were done by using an Olympus CH40 microscope and a micrometric ocular. The taxonomic literature were used to identify the zooplankton specimen (Scourfield and Harding 1966); Dussart 1969; Kiefer and Fryer 1978). Temperature $\left({ }^{\circ} \mathrm{C}\right)$ and dissolved oxygen concentration $\left(D O, m g L^{-1}\right)$ were measured in the field with a thermometer and a YSI 52 model oxygen meter, respectively.

\section{Morphological measurement}

Copepod body length was measured under the binocular microscope to the nearest $0.01 \mathrm{~mm}$ at a magnification of 10x and 40x. It was taken from the tip of the prosome to the end of the caudal rami, including the extremely long furcal setae. Some individuals were slightly bent due to fixation. Therefore, each specimen was placed laterally between 2 movable cover slips in a small droplet of lactophenol, which softened the exoskeleton (Böttger-Schnack 1989). By carefully moving the cover slips together, the specimens were straightened, and their total length could be measured. On the other hand, the width and length of each thorax segment were measured at its widest point.

Table 1. Measured distances (measurements) on the body with their corresponding abbreviations.

\begin{tabular}{lc}
\hline Measured Distance (measurement) & Abbreviation \\
\hline Cephalozom Length & $C L$ \\
Cephalozom-Cross & $C C$ \\
Cephalozom- Width & $C W$ \\
Thorax-1- Width & $T W 1$ \\
Thorax-1- Length & $T L 1$ \\
Thorax-2- Width & $T W 2$ \\
Thorax-2- Length & $T L 2$ \\
Thorax-3- Width & $T W 3$ \\
Thorax-3- Length & $T L 3$ \\
Thorax-4- Width & $T W 4$ \\
Thorax-4- Length & $T L 4$ \\
Abdomen & $A B D$ \\
Furca- Width & $F W$ \\
Furca- Length & $F L$ \\
Total Length & $T L$ \\
\hline
\end{tabular}

Table 2. The codes of populations with their number of samples (n)

\begin{tabular}{lcc}
\hline Populations & Codes & N \\
\hline Asi Female & $A S I-F M$ & 19 \\
Asi Male & $A S I-M L$ & 10 \\
Tahta Köprü Female & TAHTA-FM & 20 \\
Tahta Köprü Male & TAHTA-ML & 10 \\
Mehmetli Female & $M E H-F M$ & 20 \\
Mehmetli Male & $M E H-M L$ & 10 \\
Yenişehir Female & $Y E N I-F M$ & 20 \\
Yenişehir Male & $Y E N I-M L$ & 10 \\
\hline
\end{tabular}




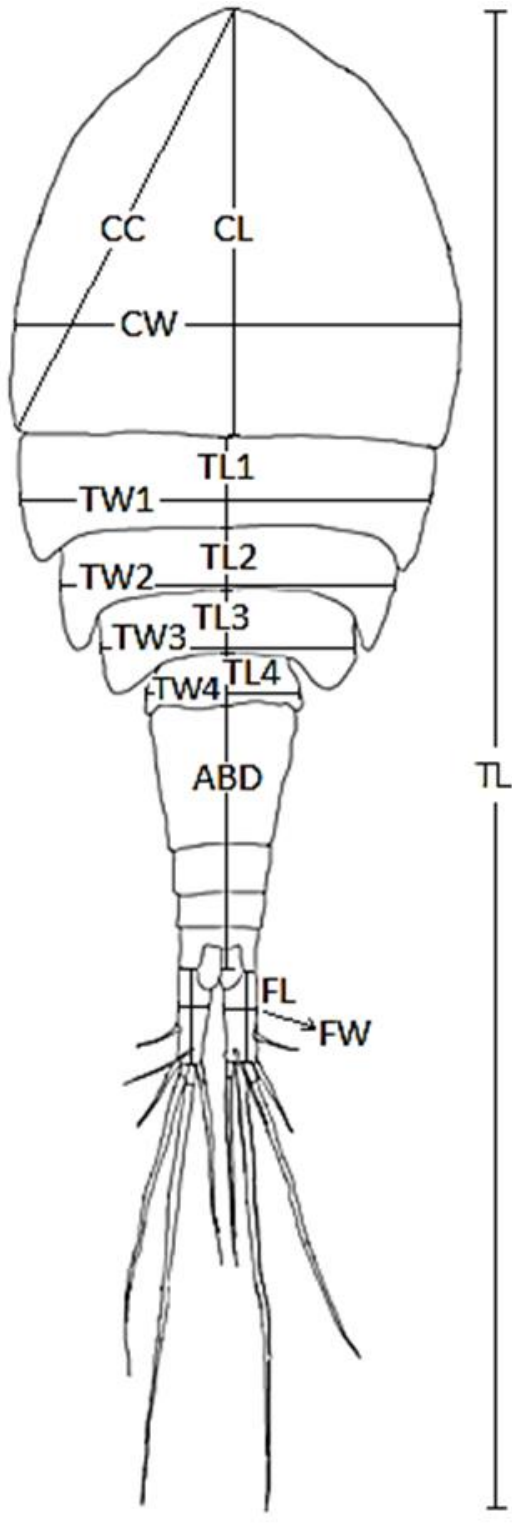

Figure 1. Measurement applications on the body of copepod

\section{Data Analysis}

In this study, two species have been studied in four water systems, so 8 populations have been formed. Before starting the main data analysis, every measurement was checked for outliers and missing values by simply plotting the data as xy pairs.

Inter and intra-population diversity were assessed in terms of coefficient of variation $(C V, \%)$, discriminate function analysis (DFA), SIMPER (Similarity Percentage), MANOVA (Multivariate Analysis of Variance) and, the Minimal Spanning Tree (MST) analysis.

Variability in each measured distances or measurements was qualified by the coefficient of variation $(C V, \%)$. Then, to find an overall variability value for any population, mean $C V$ value calculated as fallowing;

$$
C V_{\text {Overall }}=\frac{\sum C V_{i}}{n}
$$

Where, $C V_{\mathrm{i}}$ : is the $C V$ value of the i'th measurement and $\mathrm{n}$ : is the number of measurements.

The best model for the standardization of the morphometric data was the regression of Elliott et al. (1995). This model removes the size component from the shape measurements (allometry). Due to sexual dimorphism, standardization was applied for both sexes separately. The model is defined by the following equation:

$$
M s=M o\left[\frac{L s}{L o}\right]^{b}
$$

Where, $M s=$ standardized measurement, $M o=$ measured character length $(\mathrm{mm}), L s=$ overall (arithmetic) mean standard length $(\mathrm{mm})$ for all individuals from all populations of each sex, $L o=$ standard length $(\mathrm{mm})$ of specimen, and " $b$ " was estimated for each character from the observed data using the non-linear equation,

$$
M=a L^{b} .
$$

The standardized morphometric values of the populations were analyzed within each sex and among sexes and compared by means of discriminate function analysis $(D F A)$. This multivariate analysis allowed us to determine which combinations of variables (distances) discriminated best among populations and detected which populations were the most different (Ruiz-Campos et al. 2003).

Along with the DFA, SIMPER (Similarity Percentage) was used for assessing which measurements are primarily responsible for an observed difference between groups of samples or populations (Clarke 1993).

MANOVA (Multivariate Analysis of Variance) was used to test the overall differences among the populations without separating sexes.

Generally, the level of sexual dimorphism is evaluated by the ratio of female to male length (Anufriieva and Shadrin 2014). In this study, as in case for $C V$, an overall sexual dimorphism value for each population have been calculated. To compare the rates of sexual dimorphism among the water systems one-way PERMANOVA analysis was used.

The Minimal Spanning Tree (MST) analysis finds the shortest possible set of lines connecting all points (Dussert et al. 1987). Therefore, it was used to detect link or links among the populations. All calculations and statistical analysis were conducted using MS Excel and PAST software (Paleontological statistics, Version 3.20) (Hammer et al. 2001). 


\section{Results}

\section{Some properties of studied locations}

Temperature range mean dissolved oxygen level, fish presence, kind of environment, altitude, surface area, and the maximum depth of the studied areas were given into MTS analysis graph (Figure 4).

Inter and Intra-population variability (diversity)

Some descriptive statistics of measured distances on the body of $M$. leuckarti specimen from the 8 populations were given in Table 3 and Table 4. Based on the these values, the overall variability within (intra-population diversity) ASI-ML(Asi-male), ASI$F M$ (Asi-female), $M E H-M L$ (Mehmetli-male), $M E H$ $F M$ (Mehmetli-female), TAHTA-ML (Tahta Köprümale), TAHTA-FM (Tahta Köprü-female),YENI-ML
(Yenişehir-male) and YENI-FM (Yenişehir-female) populations were calculated as $4.16 \%, 3.85 \%, 5.08$ $\%, 4.34 \%, 4.56 \%, 3.65 \%, 5.14 \%$ and $4.70 \%$, respectively. Considering sexes, intra-population variability was bigger in male than that of female populations in each water body. Also, inter-population diversity among male populations was $(8.46 \%)$ bigger than inter-population variability (diversity) among female populations $(8.04 \%)$. In inter-population diversity among male populations, the Furca Width- $F W$ (12.44 \%), Abdomen- $A B D$ $(11.98 \%)$ and Thorax4 Width-TL4 (10.05\%) measurements were having three the biggest coefficient of variation $(\mathrm{CV})$, whereas for female populations they were Thorax Width-TL4 (11.66\%), Thorax2 Length-TL2 (10.36 \%) and Thorax3 Length-TL3 (9.40\%) (Table 3 and Table 4).

Table 3. Some descriptive statistics of measured distances on the body of M. leuckarti specimen and Sexual Dimorphism rate by populations and locations.

\begin{tabular}{|c|c|c|c|c|c|c|c|c|c|}
\hline & & $\begin{array}{c}A S I-M L \\
\mathrm{n}: 10\end{array}$ & $\begin{array}{c}A S I-F M \\
\text { n:19 }\end{array}$ & $\begin{array}{c}M E H-M L \\
\text { n:10 }\end{array}$ & $\begin{array}{c}M E H-F M \\
\text { n:20 }\end{array}$ & $\begin{array}{c}\text { TAHTA-ML } \\
\text { n:10 }\end{array}$ & $\begin{array}{c}\text { TAHTA-FM } \\
\text { n:20 }\end{array}$ & $\begin{array}{c}Y E N \dot{I}-M L \\
\text { n:10 }\end{array}$ & $\begin{array}{c}\text { YENI-FM } \\
\mathrm{n}: 20\end{array}$ \\
\hline & Mean & 57.50 & 87.89 & 57.75 & 90.95 & 50.30 & 83.10 & 53.30 & 82.45 \\
\hline \multirow[t]{2}{*}{$T L$} & $S d$ & 1.18 & 3.86 & 1.96 & 1.73 & 1.16 & 2.40 & 1.95 & 2.39 \\
\hline & Mean & 38.40 & 61.08 & 41.40 & 63.75 & 37.40 & 60.08 & 35.45 & 56.05 \\
\hline \multirow[t]{2}{*}{$C L$} & $S d$ & 1.07 & 2.32 & 1.17 & 1.37 & 0.74 & 2.07 & 1.38 & 1.96 \\
\hline & Mean & 41.50 & 66.79 & 43.20 & 66.65 & 38.40 & 61.85 & 37.90 & 59.00 \\
\hline \multirow[t]{2}{*}{$C C$} & $S d$ & 0.71 & 1.99 & 1.62 & 1.53 & 0.66 & 1.46 & 0.74 & 1.81 \\
\hline & Mean & 32.10 & 59.47 & 33.15 & 57.95 & 28.60 & 52.40 & 28.60 & 49.28 \\
\hline \multirow[t]{2}{*}{$C W$} & $S d$ & 0.74 & 1.98 & 1.81 & 1.00 & 0.70 & 1.50 & 1.35 & 1.27 \\
\hline & Mean & 30.60 & 54.05 & 30.45 & 52.20 & 26.55 & 47.08 & 27.10 & 45.28 \\
\hline \multirow[t]{2}{*}{$T W 1$} & $S d$ & 0.84 & 2.09 & 0.50 & 1.40 & 0.60 & 1.26 & 1.10 & 1.59 \\
\hline & Mean & 11.30 & 18.24 & 10.35 & 17.28 & 9.60 & 16.13 & 10.00 & 14.73 \\
\hline \multirow[t]{2}{*}{$T L 1$} & $S d$ & 0.59 & 0.73 & 0.75 & 0.82 & 0.61 & 0.76 & 0.00 & 1.06 \\
\hline & Mean & 25.55 & 43.97 & 25.05 & 41.55 & 21.85 & 38.08 & 22.40 & 35.50 \\
\hline \multirow[t]{2}{*}{$T W 2$} & $S d$ & 0.60 & 1.01 & 1.38 & 0.99 & 0.75 & 0.83 & 1.35 & 1.39 \\
\hline & Mean & 10.55 & 16.11 & 8.80 & 15.28 & 9.60 & 14.23 & 9.25 & 12.70 \\
\hline \multirow[t]{2}{*}{$T L 2$} & $S d$ & 0.37 & 0.83 & 0.79 & 0.97 & 0.84 & 0.77 & 0.42 & 0.70 \\
\hline & Mean & 20.80 & 35.05 & 20.00 & 31.85 & 17.65 & 29.95 & 18.00 & 28.85 \\
\hline \multirow[t]{2}{*}{ TW3 } & $S d$ & 0.42 & 0.83 & 1.05 & 0.88 & 0.63 & 0.72 & 0.82 & 1.17 \\
\hline & Mean & 8.20 & 12.95 & 7.90 & 11.45 & 8.10 & 11.55 & 6.90 & 10.78 \\
\hline \multirow[t]{2}{*}{$T L 3$} & $S d$ & 0.63 & 0.96 & 0.74 & 0.89 & 0.74 & 0.51 & 0.52 & 0.70 \\
\hline & Mean & 12.95 & 21.95 & 12.20 & 19.93 & 11.40 & 18.83 & 11.65 & 18.25 \\
\hline \multirow[t]{2}{*}{$T W 4$} & $S d$ & 0.37 & 0.60 & 0.42 & 0.73 & 0.39 & 0.61 & 0.47 & 0.70 \\
\hline & Mean & 4.90 & 6.84 & 5.05 & 5.90 & 4.60 & 5.80 & 4.55 & 6.08 \\
\hline \multirow[t]{2}{*}{$T L 4$} & $S d$ & 0.57 & 0.55 & 0.44 & 0.72 & 0.39 & 0.52 & 0.37 & 0.59 \\
\hline & Mean & 35.20 & 58.50 & 38.85 & 48.80 & 29.15 & 48.98 & 31.85 & 50.58 \\
\hline \multirow[t]{2}{*}{$A B D$} & $S d$ & 1.62 & 2.74 & 1.62 & 1.68 & 1.78 & 2.54 & 1.94 & 2.74 \\
\hline & Mean & 2.95 & 4.00 & 3.00 & 4.30 & 2.55 & 4.00 & 2.30 & 3.90 \\
\hline \multirow[t]{2}{*}{$F W$} & $S d$ & 0.16 & 0.00 & 0.00 & 0.30 & 0.16 & 0.00 & 0.26 & 0.21 \\
\hline & Mean & 8.35 & 13.76 & 7.30 & 11.55 & 7.05 & 12.00 & 7.45 & 11.68 \\
\hline$F L$ & $S d$ & 0.47 & 0.39 & 0.48 & 0.48 & 0.16 & 0.49 & 0.50 & 0.44 \\
\hline \multicolumn{2}{|c|}{ Sexual Dimorphism } & \multicolumn{2}{|c|}{1.61} & \multicolumn{2}{|c|}{1.55} & \multicolumn{2}{|c|}{1.62} & \multicolumn{2}{|c|}{1.56} \\
\hline
\end{tabular}


Table 4. Variation Coefficients $(C V, \%)$ of measurements by locations and sexes.

\begin{tabular}{|c|c|c|c|c|c|c|c|c|c|c|}
\hline & $A S I-M L$ & ASI-FM & $M E H-M L$ & MEH-FM & $T A H T A-M L$ & $T A H T A-F M$ & YENİ-ML & YENİ-FM & $F M-C V$ & $M L-C V$ \\
\hline$T L$ & 2.05 & 4.39 & 3.40 & 1.90 & 2.31 & 2.89 & 3.65 & 2.90 & 5.13 & 6.40 \\
\hline$C L$ & 2.80 & 3.80 & 2.84 & 2.15 & 1.97 & 3.44 & 3.90 & 3.50 & 5.63 & 6.36 \\
\hline$C C$ & 1.70 & 2.98 & 3.75 & 2.30 & 1.71 & 2.36 & 1.95 & 3.06 & 5.86 & 6.02 \\
\hline$C W$ & 2.30 & 3.33 & 5.46 & 1.72 & 2.44 & 2.86 & 4.72 & 2.58 & 8.02 & 7.81 \\
\hline$T W 1$ & 2.76 & 3.87 & 1.63 & 2.68 & 2.25 & 2.68 & 4.06 & 3.50 & 7.93 & 7.09 \\
\hline$T L 1$ & 5.19 & 4.02 & 7.22 & 4.74 & 6.40 & 4.71 & 0.00 & 7.18 & 9.40 & 8.12 \\
\hline$T W 2$ & 2.34 & 2.29 & 5.52 & 2.37 & 3.42 & 2.18 & 6.03 & 3.90 & 8.59 & 8.14 \\
\hline$T L 2$ & 3.50 & 5.13 & 8.96 & 6.33 & 8.78 & 5.41 & 4.59 & 5.48 & 10.36 & 9.40 \\
\hline$T W 3$ & 2.03 & 2.37 & 5.27 & 2.75 & 3.55 & 2.42 & 4.54 & 4.06 & 8.01 & 8.00 \\
\hline TL3 & 7.71 & 7.38 & 9.34 & 7.75 & 9.11 & 4.42 & 7.48 & 6.47 & 9.40 & 10.60 \\
\hline TW4 & 2.85 & 2.73 & 3.46 & 3.67 & 3.46 & 3.26 & 4.07 & 3.82 & 7.86 & 6.00 \\
\hline$T L 4$ & 11.58 & 8.10 & 8.67 & 12.17 & 8.57 & 9.02 & 8.11 & 9.73 & 11.66 & 10.05 \\
\hline$A B D$ & 4.60 & 4.69 & 4.16 & 3.45 & 6.11 & 5.19 & 6.10 & 5.42 & 8.98 & 11.98 \\
\hline$F W$ & 5.36 & 0.00 & 0.00 & 6.96 & 6.20 & 0.00 & 11.23 & 5.26 & 5.79 & 12.44 \\
\hline$F L$ & 5.68 & 2.81 & 6.62 & 4.19 & 2.24 & 4.06 & 6.67 & 3.75 & 8.09 & 8.55 \\
\hline Overall $C V$ & 4.16 & 3.85 & 5.08 & 4.34 & 4.56 & 3.65 & 5.14 & 4.70 & 8.04 & 8.46 \\
\hline
\end{tabular}

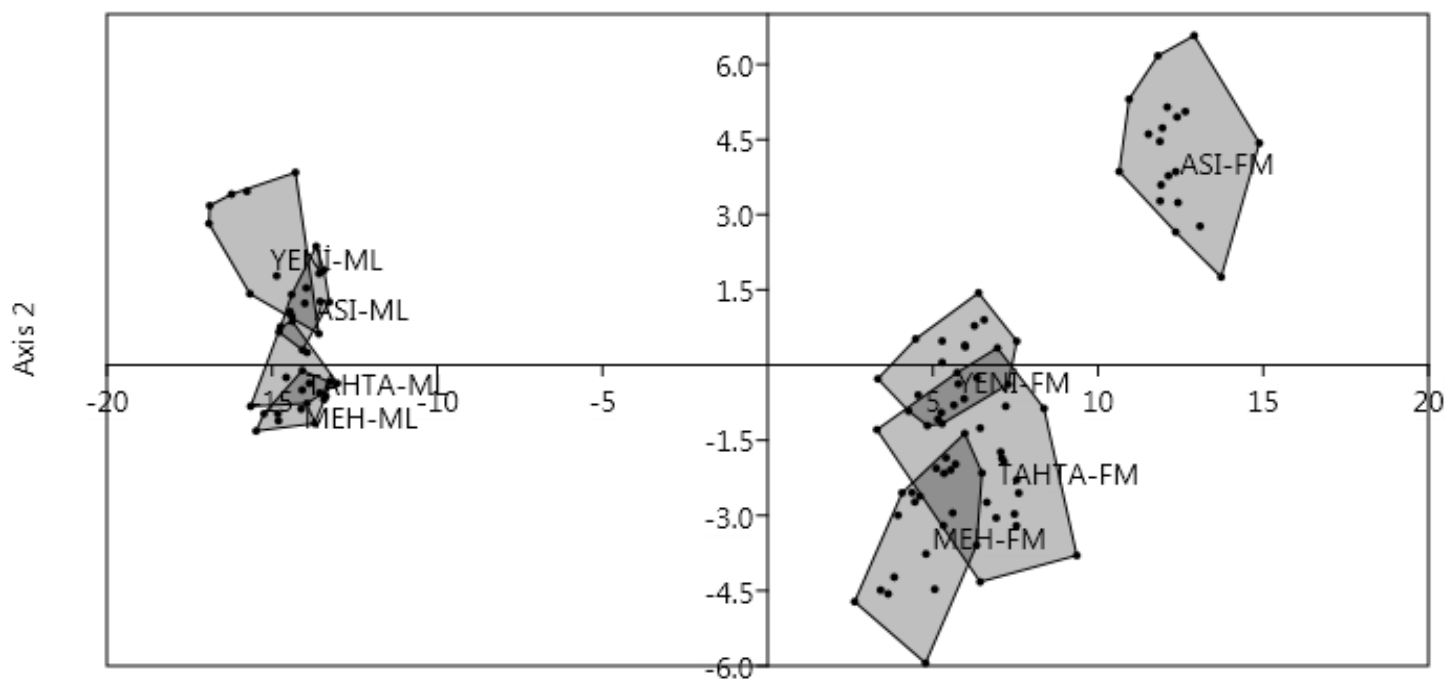

Axis 1

Figure 2. DFA results for M. leucarti populations.

Based on the DFA analysis, two main groups, one was located on the left $\mathrm{X}$-axe (male) and other was located on right $\mathrm{X}$-axe (female) of $D F A$ graph, were clearly observed. In $D F A$ the first two functions (axes) were accounted for $98.49 \%$ variance (Figure 2).

The number of the re-assigned specimen based on Jackknife estimation procedure (group assignment) were shown into a confusion matrix (Table 5). In that matrix, specimens were reorganized by leave one out cross validation. For example, 14 out of 20 specimens belong to $M E H-F M$ were remained or re-assigned $(R S)$ by Jackknife estimation procedure again into the $M E H-F M$ populations. So, the ratio of $R S$ (n: 14) to sampled number ( $T, \mathrm{n}: 20)$ for $M E H-F M$ was $70 \%$ $(14 * 100 / 20)$. By the same approach, the ratio of $R S$ to $T$ for the populations were (\%); ASI-FM: 100 , MEH-FM: 70, TAHTA-FM: 70, YENI-FM: 85, ASIML: 90, MEH-ML: 80, TAHTA-ML: 40, YENI-ML: 60.

MANOVA analysis showed that there are no significant differences ( $p>0.01)$ among the male populations; whereas, there is statistical significance $(\mathrm{p}<0.01)$ among the female populations with changing p-values (Table 6). In accordance with the $D F A$ and the Jackknife procedure the ASI-FM was found as the most different populations among others (Figure 2, Table 5).

The contribution of measurements to discriminate for all populations, among female populations and among male populations were given in Figure 3. Based on SIMPER analysis the most 
distinctive measurements contribute the diversity for all populations were CW (19.32\%), CC (17.92\%), $C L(16.13 \%)$; for female populations; $A B D(31.95$
$\%), C W(12.25 \%), T W 1(12.10 \%), C C(9.87 \%)$ and for male populations; $C L-(23.97 \%), A B D(17.75 \%)$, $C C(14.45 \%), C W(11.61 \%)$ and so on (Figure 3).

Table 5. The confusion matrix for $M$. leucarti populations based on the Jackknife estimation procedure.

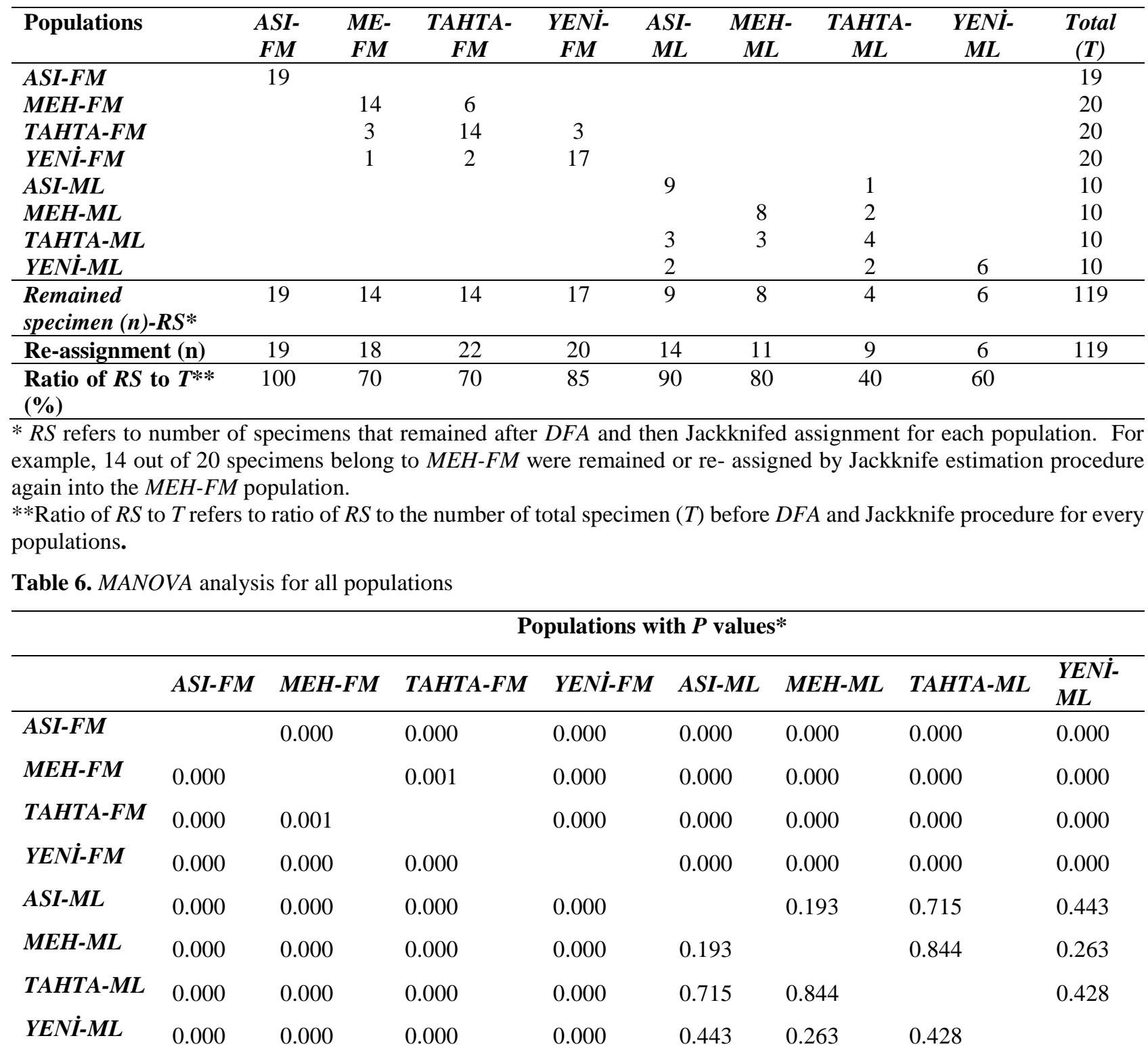

$* \mathrm{p}<0.05$ indicates a significant difference, $\mathrm{p}>0.05$ indicates non-significant difference among the populations.

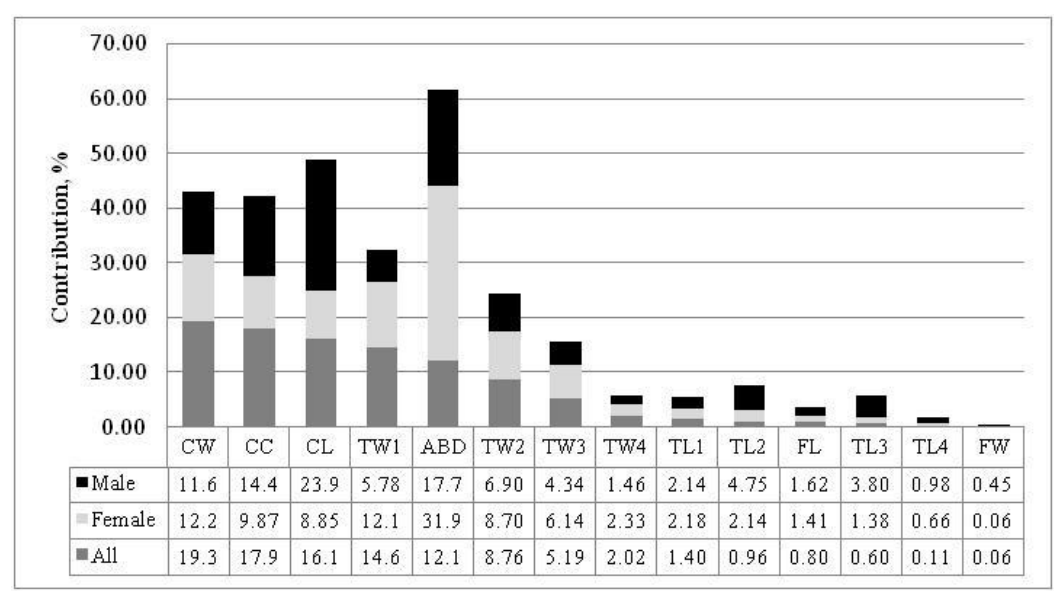

Figure 3. The contribution of measurements to discriminate for all populations, among female populations, and among male populations. 


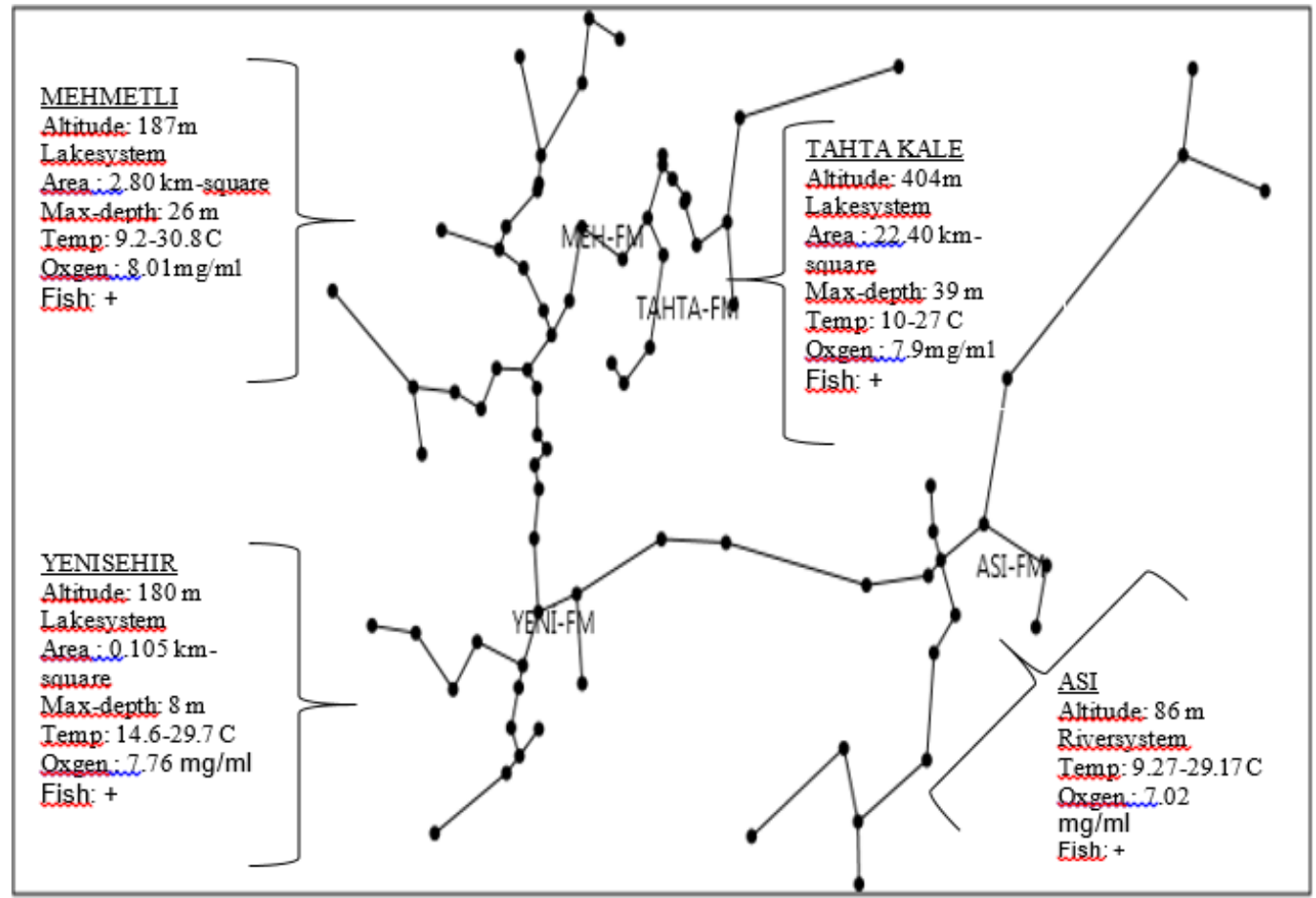

Figure 4. MST analysis graph with some properties of studied locations.

The Minimal Spanning Tree (MST) analysis for females showed that in general ASI-FM population links with YENI-FM, MEH-FM links with TAHTA$F M$ populations, YENI-FM links with $M E H-F M$ and TAHTA-FM (Figure 4). To understand the factors effecting on the diversity of body size the $M S T$ graph was combined with some properties of four water systems. Since there were no statistical differences among the male populations, the MST analysis was not conducted for male populations.

\section{Sexual dimorphism in body size}

In all water systems, male copepods were smaller than females in overall size. The mean rate of sexual dimorphism for the populations of ASI, MEH, TAHTA, and YENI were 1.61, 1.55, 1.62 and 1.56, respectively (Table 3 ), and there was no significant difference among them (One-way PERMANOVA: $\mathrm{F}=1.03, \mathrm{p}=0.3932$ ).

\section{Discussion}

There were both intra-specific and inter-specific variations in the measured distances of the different populations for each sex of M. leuckarti. At intrapopulation level, these measurements were also having different variable patterns for all populations. But, the overall variations in all male populations were bigger than that of the female populations for each water systems (Table 4). Interestingly, the three consecutive measurements namely $T L 4, A B D$, and $F W$ had the highest $C V$ values among male populations, and other three consecutive measurements having the highest $C V$ values among male populations were $T L 2, T L 3$, and $T L 4$.
It was found that there is inconstant variability on body size in all populations. In addition, DFA analysis (Figure 2) shows explicitly two different groups, namely female and male populations, most probably due to sexual dimorphism, which is discussed later in detail, observed in copepod species.

The inter-population variability was assessed with DFA, MANOVA and MST analyses. From those analyses, there is a phenomena which there was no significant differences among the male populations in terms of morphological diversification. Although $D F A$ and Jackknife estimation procedures showed that there was specimen assignment tendency with changing numbers among the female populations, except ASI-FM, all female populations were statistically different from each other. In all analyses, it was clearly seen that ASI-FM population was very different from other female populations as well $(\mathrm{p}<0.0000)$.

In that study, the question has been emerged that why only significance differences were observed among female populations In order to evaluate the morphological difference between populations, some properties of water systems were examined. These properties were temperature range and mean dissolved oxygen, fish presence, kind of environment, altitude, surface area and maximum depth (Figure 4).

Anufriieva and Shadrin (2014), explained the constant linear dimensions and the level of their variation in A. salinus populations as to a certain extent they depended on temperature, salinity, and density of population. Their results lead to the 
general conclusion that the impacts of factors on linear morphological characteristics and their variability can manifest itself in different ways at intra-population and inter-population levels. They also stated that in copepods, variability can increase when animals are near limit values of factors, such as temperature, salinity or increased population density, but, inter-population differences of A. salinus cannot be explained by only studied factors, and it is assumed that there are some overlooked factors as well as differences in the genetic architecture of populations.

Fifty-two freshwater planktonic copepod populations, Cyclops scutifer G.O. Sars, from Eurasia and North America, were studied to detect variations in morphology by means of morphometric analysis. It was revealed that many morphological relations were correlated with environmental factors such as depth, temperature, and trophic condition. Therefore, it was suggested that variations in body proportions were related to environmental factors rather than geographic distance (Elgmork and Halvorsen 1998).

Hausch et al. (2013), stressed that a wide variety of environmental gradients, including nutrient levels, temperature conditions, and predation pressure are likely to influence on the relationships between copepod body size and lake size and location. They also expressed that from studies of copepod body size along altitudinal and latitudinal gradient it is apparent that copepods are generally smaller at higher temperatures.

It was found that zooplankton body size decreases with temperature, increasing with latitude, elevation, and lake depth and decreases with visual predation threat, which is also expected to decrease with lake depth due to the presence of piscivores and a larger deep-water refuge (Hausch et al. 2013).

In most Calanoida species, other than very few exceptions, females are always bigger than males. The smaller size of calanoid males is generally attributed to their shorter developmental span of copepodite stage, which enables males to fertilize females as soon as molting. In zooplankton, the smaller size and the reduced feeding activity of males could maximize female fecundity by decreasing intra-specific competition for food. In unpredictable environments where generalism is favored, the sexual size-dimorphism may represent a way to widen the ecological niche of the species (Anufriieva and Shadrin 2014).

Gilbert and Williamson (1983) emphasized that copepods inhabit a remarkable diversity of habitats that range from small temporary pools to the abyssal depths of the ocean. The wide range of environmental conditions undoubtedly contributes to the variability in the taxon's patterns of sexual dimorphism. There are several possible adaptive advantages of having larger females than males. Perhaps the most obvious one is that females have a greater investment in offspring, both in terms of biomass contributed and, in those species that carry their eggs, of energy used to carry them.

The mean manifestation level of sexual dimorphism (mean $\pm S D$, range: min-max) observed in family cyclopoida, considering 16 generas and 86 species, was $1.48 \pm 0.367$ (range: $0.72-3.36$ ), and the difference in sexual dimorphism levels was explained as a function of variation in the environmental temperature or food conditions under which the distinct generations of multi-voltine populations develop (Gilbert and Williamson 1983).

For a copepod species, Arctodiaptomus salinus (Daday, 1885), populations in the Crimean water bodies, the average index of sexual dimorphism was1.11 (1.00-1.3, $C V=7.51)$, whereas, those of "small" and "large" sized populations were 1.10 and 1.13, respectively. Data obtained from different periods of a single lake (Lake Yanyshskoye) showed that this index could vary widely within a population. Sexual dimorphism of $A$. salinus manifests not only in linear dimensions and proportions of the body but also in variability level and reactions to the fluctuations of environmental conditions (Anufriieva and Shadrin 2015).

Considering temperature, latitude and lake depth regarding the mean body size of female populations, our findings were not compatible with previous studies (Table 3 and Figure 4). Capture success by planktivorous fish depends largely on prey visibility and the ability of the prey to escape. Body transparency of copepods decreases their susceptibility to visual predators, but this trait has only limited significance because many vital processes interfere with it. For example, the gut of a feeding copepod is usually distinctly colored, oocytes developing in the gonads of females are clearly visible and are often dark-colored, reserve lipids are often pigmented, and movements of feeding appendages make copepods more conspicuous (Pasternak et al. 2006). So, it was expected to interactions of some environmental factors on body size variations, but the reason of why there were only significant variations between body sizes of female populations may be due to interaction of sexual dimorphism, physiology of female copepod and fish predations. Fish predation on copepod is affected by fish species, fish population density and the structure of age classes. In this manner, it would be reasonable to expect the fishing could be a latent factor effecting variations on body size of copepods.

In conclusion, both intra- and inter-specific variability on body size were observed in the 
populations of $M$. leuckarti. Intra-population diversity was bigger in male than that of female populations in each water body. Also, interpopulation diversity among male populations was bigger than inter-population diversity among female populations. There was statistically significance among the female populations; whereas, no significant differences were detected among the male populations. The variability observed most probably due to the combination of environmental factors, sexual dimorphism, physiology of female copepod, fish predation and the characteristics of water systems.

As other copepod species, in general, sexual dimorphism was observed in all water body. It was clear evidence that the specimen living in the pond and lake systems were closer than river systems in terms of body size especially for female ones of copepods. Also, regarding the significant variations between female populations, it would be reasonable to expect the fishing could be a latent factor effecting variations on body size of copepods.

\section{Acknowledgements}

We thank Ece KILIC for providing comments that improved the quality of the manuscript and for correcting the English.

\section{References}

Anufriieva EV, Shadrin NV. 2014. Factors determining the average body size of geographically separated Arctodiaptomus salinus (Daday, 1885) populations. Zoological Research. 35(2):132-141. doi: 10.11813'j.issn.0254-5853.2014.2.132

Anufriieva EV, Shadrin NV. 2015. Morphometric variability of Arctodiaptomus salinus (Copepoda) in the Mediterranean-Black Sea region. Zoological Research. 36(6):328-336. doi: 10.13918/j.issn.2095-8137.2015.5.328

Böttger-Schnack R. $1989 . \quad$ Body length of female Macrosetella gracilis (Copepoda: Harpacticoida) from various depthzones in the Red Sea. Mar Ecol Prog Ser. 52:33-37.

Clarke KR. 1993. Non-parametric multivariate analysis of changes in community structure. Aust $\mathrm{J}$ Ecol. 18(1):117-143. doi: 10.1111/j.1442-9993.1993.tb00438.x

Dussart B. 1969. Les Copepodes des Eaux Continentales D'europe Occidentale, Tome II: Cyclopoides et Biologie. Paris: N. Boubee et Cie 292 p.

Dussert C, Rasigni M, PalmariJ, Rasigni G, Llebaria A, Marty F.1987. Minimal spanning tree analysis of biological structures. J Theor Biol. 125(3):317-323. doi: 10.1016/S0022-5193(87)80063-2

Elgmork K, Halvorsen G. 1998. Intraspecific morphological variation in a freshwater copepod
(Crustacea) in relation to geographic distribution and environment. Can J Zool. 76(4):751-762.

doi: 10.1139/z97-204

Elliott NG, Haskard K, Koslow JA. 1995. Morphometric analysis of orange roughy (Hoplostethus atlanticus) off the continental slope of southern Australia. J Fish Biol. 46(2):202-220.

doi: 10.1111/j.1095-8649.1995.tb05962.x

Gilbert JJ, Williamson CE. 1983. Sexual dimorphism in zooplankton (Copepoda, Cladocera, and Rotifera). Annu Rev Ecol Syst. 14:1-33. doi: 10.1146/annurev.es.14.110183.000245

Hammer Ø, Harper DAT, Ryan PD. 2001. PAST: Paleontological Statistics Software Package for Education and Data Analysis. Palaeontol Electron. 4(1):1-9.

Hausch S, Shurin JB, Matthews B. 2013. Variation in body shape across species and populations in a radiation of diaptomid copopods. Plos One. 8(6):1-11. doi: 10.1371/journal.pone.0068272

Hribar LJ, Reid JW. 2008. New records of copepods (Crustacea) from the Florida Keys. Southeast Nat. $7(2): 219-228$. doi:10.1656/15287092(2008)7[219:NROCCF]2.0.C $\mathrm{O} ; 2$

Kiefer F, Fryer G. 1978. Das Zooplankton der Binnengewasser 2. Teil, Stuttgart: E. Schweizerbart'scheVerlagsbuchhandlung $380 \mathrm{p}$.

Pasternak AF, Mikheev VN, Wanzenböck J. 2006. How plankton copepods avoid fish predation: from individual responses to variations of the life cycle. Journal of Ichthyology. 46(2):220-226. doi: 10.1134/S0032945206110129

Reid JW, Pinto-Coelho RM. 1994. An Afro-Asian continental copepod, Mesocyclops ogunnus, found in Brazil; with a new key to the species of Mesocyclops in South America and a review of intercontinental introductions of copepods. Limnologica. 24(4):359-368.

Reid JW, Saunders JF. 1986. The distribution of Mesocyclops aspericornis (von DADAY) in South America. J Crustacean Biol. 6(4):820-824. doi: 10.1163/193724086X00604

Ruiz-Campos G, Camara-Rosales F, Varela-Romero A, Sánchez-González S, De la Rosa-Vélez J. 2003. Morphometric variation of wild trout populations from northwestern Mexico (Pisces: Salmonidae). Rev Fish Biol Fisher. 13(1):91-110. doi: 10.1023/A:1026367113735

Scourfiled DJ, Harding JP. 1966. A key to the British Freshwater Cladocera. United Kingdom: Freshwater Biological Association Scientific Publications $55 \mathrm{p}$.

Suárez-Morales E, Mercado-Salas NF, Álvaro MR. 2011. Morphological variability and distribution of the exotic Asian Mesocyclops thermocyclopoides (Copepoda: Cyclopoida): in the Neotropical region. Zoologia. 28(5):673-679. doi: 10.1590/S1984-46702011000500016 